\title{
INTERESTS - THE TRIGGERS OF CREATIVE MOTOR LEARNING AND ACHIEVEMENTS OF PUPILS
}

\author{
Nataša Sturza Milić, PhD \\ Preschool Teacher Training College \\ "Mihajlo Palov“ in Vrsac (Serbia) \\ e-mail: natasasturza@gmail.com
}

\begin{abstract}
S u $\boldsymbol{m} \boldsymbol{m} \boldsymbol{a} \boldsymbol{r} \boldsymbol{y}$
Interests belong to a group of motivational, dynamic personality traits and as such they could be observed as important inner triggers of activities in all areas of creativity. Some researches in the field of education emphasize the processes of discovering, following and developing particular interests as requirements for the success of education in general. Due to the importance of analyzing still insufficiently studied relations between abilities, interests and activities of pupils, especially when a quality strategy of working with motor gifted pupils in the range of process of Physical Education is in question, the aim of this paper has been to find out whether there is a relation between motor success of pupils in the early years of primary school and interests in physical activity. The results have shown that there is a statistically significant correlation $(r=0.549 ; p=0.00)$ between motor success of pupils and interests in physical education, recognized by teachers. The results of this research can serve as a basis for a reliable identification of motor gifted pupils and further work with them in the range of Physical Education, extra-curriculum activities and special school programmes for the gifted.
\end{abstract}

Key words: interests of pupils, motor success, Physical Education

\section{Introduction}

Since interests belong to the group of motivational, dynamic personality traits they can be viewed in the light of significant drivers of activity in all spheres of creativity, thus including the sphere of motor creativity. It has been proven useful, but also necessary, in the study of child development (especially gifted behaviour), among other characteristics of children such as curiosity, motor activity, independence and verbal expression, to also examine their interests as well (Andrilović and Čudina 1988; Winner 2000; Malušić 2000; Sturza Milić 2009). Regarding the identification of creative expression in the function of development, especially in younger children, Maksic (1999) recommends the identification through the support of interests of the child. Comparing the results of students who 
were selected for inclusion in special programs for the gifted on the basis of interests (and therefore worked with as if they were gifted) and students included on the basis of the measurement of the classic indicators of talent, it has been shown that among them there were no significant differences, i.e., students were equally successful and had similar achievements (Cropley 1993, by, Maksic 1999). Almost every time a child exhibits talent, he also expresses interest. Interests can be viewed in the context of a "catalyst" that positively influences the development of giftedness and talent (Gagne 1993, 2010). Some authors warn that one should be careful when considering this relationship, because there are always incompetent and disinterested students, and disinterested talents (Pantic 1980). On the other hand, if talents of students are judged only on the basis of expressed interest, it can lead to problems, both in quality of identification, and in the position of other students who are gifted (Havelka and Lazarevic 1981). It must be borne in mind that students of junior school age have a lot of interests, that an interest in one activity at that age does not mean indifference to other activities and that there is a factor in children "to love everything" (Pantic 1980).

As a result of a specific relationship between the child and reality in which he lives, there is a child's expression (Lazarevic 2000). Through the experience of reality and experience of the environment, the child, moved by curiosity, skills, interests, strive for self-fulfilment, as well as by internal drivers, and encouraged and supported by the environment, exhibits creativity, both in daily spontaneous activities and at school. Children's interests are important internal drivers of activity in all spheres of creativity. For a school to be encouraging children's creativity, it should support curiosity, intrinsic motivation, interest in specific fields of human activity and creation. The importance of interest as components of motivation has been highlighted by recent authors. One way to develop students' interest in the activity is finding meaning and value in these activities, as recommended by the objectives and achievements of the initial interest that lead to perceptions of the value of the assignment, which subsequently promotes the development of interest and learning (Hulleman et al. 2008). Intense reaction to the environment describes many people with high skills. It seems that this sensitivity can be developed, i.e. learned through the reference of attention and involvement by parents, teachers, professors and others. Such differentiated perception of the child may develop categorical values and interests, and, if surrounded by a stimulating environment with great possibilities for motor expression (different types of movement and motor facilities, a wealth of space, equipment, apparatus, motor games, etc), the child can take the opportunities available in his categories of perception and motor stimulation evaluated by the richness of these criteria, and not just superficially (Sturza Milic 2009b). Research works in education of gifted younger children emphasize the processes of detection, monitoring and development of special interests, as a condition for the success of education in general. Different interests of younger gifted children should take precedence over "rough" school programs. Interest is the expression of strong emotions and it is therefore crucial for the effectiveness of learning. What interests us is learned faster and with less effort than what we are not interested in (Semorie 1976, according to Stankovic-Jankovic 2009). Thus, the most 
gifted children progress the most in those areas they are most interested in (Cvetković-Lay and Sekulic-Majurec 1998; Sturza Milic 2009; Stankovic-Jankovic 2009). The analysis of existing practices can lead to a practical conclusion that proportionally expanded educational offer for gifted children in some kindergartens and schools leads to a wrong impression that children have the opportunity to choose the very programs based on their interests. This occurs despite the growing interest of younger parents of gifted children for their proper activation. In the opinion of some authors, the most successful are those curricula in which content is not only elected based on cognitive fitness, but also based on current developmental interests of children (Feberžer, Corrèze et al. 2006; Šekeljić Sturza and Milic 2010).

Interests are the driving forces of behaviour. Like other psychological functions of the child, they develop and are prone to change. Some have their roots in instincts and some of the needs that have arisen in the process of individual development of the child, in the process of adapting to the child's surrounding environment, primarily social (Vygotsky 1996b). Interest in an object, phenomenon, activity or occupation is a regular companion of our everyday life. Jordan (as, Rodic 2001, p. 26.) states that most authors consider the interest to be what is "... responsible for those strange irregularities when a person in an enterprise achieves a higher level of achievement than it could be expected from his moderate capacity, or, conversely, when an individual of high capacity achieves only moderate success because he is not interested in the job" ${ }^{1}$.

Pantic (1980) defines interest as "... a form of (usually terminal) values whose characteristic is absorption of consciousness with favourite content and/or doing chosen activities". Human interests go hand in hand with human capacities ${ }^{2}$. Almost every time children exhibit talent, they also express interest. However, we should be cautious when considering the relationship between abilities and interests, since abilities which efficiency depends on can often turn into interest, while aroused interest can correct abilities. "Even though there are two autonomous phenomena, some connection between interest and ability exists, but it is always necessary to pre-specify the type and degree of generality of both phenomena. There are always incompetent and disinterested students on the one hand, and disinterested talents on the other hand. This discrepancy explains why the correlation between interest and ability has never been perfect" ${ }^{\prime \prime}$. However, this view leads to the conclusion that the relationship between gifted behaviours and interests is an under-explored area. Iljin (1985) raises the question: To what extent preferences (interests) match the capabilities for the selected type of activity? The author believes that the skills and interests form a closed functional system with strong feedback connections. A stable interest increases the activity that is selected, promotes a better development of

${ }^{1}$ According, Rodić, R. (2001): Izabrani radovi, Savez pedagoških društava Vojvodine, Novi Sad, p.p. 26.

${ }^{2}$ Pantić, D. (1980): Interesovanja mladih, I deo - Priroda interesovanja, Istraživačkoizdavački centar SSO Srbije u saradnji sa Institutom društvenih nauka - OOUR Centar za politikološka istraživanja i javno mnjenje, Beograd, p.p. 29.

${ }^{3}$ Pantić, D. ibid, p.p. 122. 
capabilities, accelerates the formation of habits and knowledge. Teplov (1961) also states that the development of skills, like any development, does not follow a straight line. Its driving force is a battle of opposites, so that at certain stages of development it is possible to reach a contradiction between abilities and interests; however, interest cannot be developed regardless of ability.

In gifted individuals the task-oriented motivation, a great interest and love for the subject of expertise dominate (Sternberg and Luba 1993; Vinner 2000). Kvascev (1981) notes that one of the cognitive currents connects breadth and depth of particular interests with creative personality traits or considers interest as the initial phase of the creative process. Early in junior school period interest in sport is an important prerequisite for acquiring skills and habits (Bokan 1985; Čokorilo, Raič et al. 1998; Sturza Milic 2009; Šekeljić and Sturza Milic 2010). The interests in physical activity are among the most dominant and are more expressed in male students. The presence of interest in sports and recreation results in a specific application of these activities in school extracurricular forms of physical activity (Bokan 1985).

Numerous studies on the effectiveness of different methods of working with gifted students confirmed the fact that the potentially gifted students need special education treatment. The analysis of these studies, which set the relationship between the interests of students and gifted behaviour as a problem, makes it evident that they emphasize the importance of recognizing different interests of gifted behaviour, but also a need to examine this question more precisely, especially in younger children. Without diminishing the importance of interests, many authors suggest that the potential talent cannot be identified with them, and that this issue should be dealt with very carefully. On the other hand, there are studies that show an insufficient appreciation of students' interest in physical education (Malušić 2000), as well as a lack of situations to express it (Djordjevic, Radovanovic et al. 2007). Identification of gifted behaviours in different areas, performed by teachers and parents, can be made primarily based on the expressed interest of students. Students in elementary schools build an opinion and attitude to all subjects. For a successful teaching, it is necessary to establish an "interest in subjects" in students to enable them to express their abilities in a school environment, but also a likeness for a certain subject, and especially the teacher, which is not without significance for the further success of the teaching process (Radovanovic and Milosevic 2006, pp. 75). Because of the importance of analyzing the still insufficiently examined relationship between skills, interests and participation of students, especially when it comes to the quality strategy of working with students in the process of physical education, future research should be focused in that direction.

Previously presented information and research findings suggest that the relationship between motor performance and interest in students of younger ages is a significantly, but insufficiently, clarified question of theory and practice, especially in the field of education. Accordingly, the aim of this study has been to investigate whether there is a connection between the motor performance of students of junior school age and interests of students towards physical activity. Since the interest of students towards physical activity has been recognized by their teachers, the specific 
objective of this study has been to examine the competence of teachers in connection with the evaluation of students' interest towards physical activity.

\section{Method}

\section{Sample}

The sample included 500 students aged 10 from all elementary schools in Vrsac, of which 247 were girls and 253 boys. In addition, the study included 22 teachers.

\section{Procedure}

Motor testing technique involving a battery of motor tasks was used in testing of motor abilities of students. Having completed motor testing of the full sample of students, the standardization of results followed. The test results from all 11 motor tasks for each student were standardized together as one value (Z-value). This procedure was used so that each student's ranking could be compared to other students' rankings (based on overall performance in the battery of motor tasks). The opinions of teachers on students' interests towards physical activity were obtained using the rating scale that was a measuring instrument for identifying motor giftedness in junior school, designed for the purpose of the research "Motor identification of gifted junior school students" (2009). Having applied appropriate statistical procedures, the next step was to correlate Z-values recorded in applied motor tests (ZMOT) and teacher's assessments assigned to a student by answering the question: Assess student's interests in movement and activities linked to relevant movements (UCINT).

\section{Instruments}

The sample of motor tasks:

1. Standing long jump (SDALJ)

2. Endurance in pull-up position (ZGIB)

3. Sit-ups in 20 seconds (PSED)

4. 15 metre sprint from running start (TR15)

5. Hand-tapping (TAPR)

6. Agility run $10 \times 5 \mathrm{~m}$ (ČUTR)

7. Shuttle run on $20 \mathrm{~m}$ track (ŠATL)

8. Training ground with jumping and pulling through (POLI)

9. Targeting (TGAĐ)

10. Flamingo balance test with eyes closed (FLAM)

11. Sit and reach (PRSE) 
Previous studies (Sturza Milic 2009a) had found that the used batteries of motor tasks had optimal psychometric properties.

The used observational Likert scale consisted of 11 items. The first item was: Assess students' interests in movement and activities of relevant movements (UCINT). Previous studies (Sturza Milic 2009a) had found that the applied observational scale had optimal psychometric properties.

\section{Data analysis}

Data analysis included the use of Pearson linear correlation to determine the relationship between motor variables (standardized values Z) - ZMOT variables for assessing students' interest towards physical activity (students' interests in movement and activities of relevant movements) by a teacher-UCINT.

\section{Results}

This research has found that when Z-values recorded in applied motor tests (ZMOT) and teacher's assessment assigned to a student by answering the question: Assess student's interests for movement and activities of relevant movements (UCINT) are correlated there is a correlation $(r=0.549)$ at the level of significance $p=0.00$. The results are shown in Table 1 .

Table 1: The correlation coefficient between the Z-value motor testing (ZMOT) and teacher ratings in reply to the question: Assess students' interests in movement -

UCINT

\begin{tabular}{|ll|c|c|}
\hline & & ZMOT & UCINT \\
\hline Pearson & ZMOT & 1.000 & $.549^{* *}$ \\
Correlation & UCINT & $.549^{* *}$ & 1.000 \\
\hline Sig. & ZMOT & .000 & .000 \\
(2-tailed) & UCINT & .00 & 500 \\
\hline $\mathrm{N}$ & ZMOT & 500 & 500 \\
& UCINT & 500 & 5 \\
\hline
\end{tabular}

\section{Discussion}

Before we engage in a discussion of the results, it should be recalled that many researchers unrealistically equated interests and abilities in their theories and researches (Allport, by Pantic 1980). Naturally, there is a link between abilities and interests and there is a functional system with real and functional relationships between them (Iljin 1985). However, there are significant differences, which suggests that in the educational work and teaching the process of motor ability should not be identified only on the basis of interest shown by students towards physical activity. On the other hand, the correlation between the variables examined 
in this study is not surprising, given that some authors have suggested that in an early school age child's talents could also be judged based on their interests (Maksić 1998). Winner (2000) believes that gifted and talented children, besides being able to share the characteristics of fast learning and a very individual way of learning, have highly expressed interests in the field of high abilities. When teachers want to detect giftedness, they should pay attention to students who show a very high interest and motivation (Csikszentmihalyi 1996). Malušić (2000) finds that teachers rated the gifted students primarily on the basis of expressed interest in a particular area or activity, and that the identification of students for extra work in school practice is usually based on the expressed interest of students and less on the basis of ability. Although the link between motor performance and teachers' assessment of students' interests in this study is statistically significant, these results should be approached with caution since the structure of interests is complex and very complicated and, unfortunately, this is a technical problem that is usually not available to a larger number of teachers. Although interests basically direct a person toward a process, teachers should be aware of the fact that they may not always lead to increased activity of pupils, but may have a superficial dimension. Often, it could be heard in schools that interests are variable over relatively short time periods. A person who expresses interest in a particular area may not be automatically gifted in that area and have good abilities and character to achieve the gifted range. Therefore, the interest could be viewed as one of the helping criteria in the identification of various inter-disciplinary behaviours of gifted students. In recognition of giftedness based only on the interests of the students there are further dangers. The presence of gifted students in the classroom, who haven't been identified by a teacher in his/her pedagogical strategy as gifted, but only as active, hardworking and successful, makes the teacher evaluate all other students in comparison with them. This is harmful to the gifted students who should have a different pedagogical guidance in physical education classes and structural upgrading of experience (they are not recognized as gifted, but as more interested), but also to the other students who realize that all their efforts in relation to the demands of teachers (set unrealistically) are largely without value (Havelka and Lazarevic 1981). The results of this study suggest that the importance of interest in educational work and the process of teaching of physical education should not be neglected. Certainly, in order to improve strategies of working with motor gifted students and other students in the range of physical education, the relationship between interests and various gifted behaviours in younger children should be examined more accurately.

\section{Bibliography}

- Bokan, B. (1985): Vančasovne aktivnosti učenika u fizičkom vaspitanju u savremenoj pedagoškoj teoriji i praksi, Doktorska disertacija, FFV, Beograd. 
- Czikszentmihalyi, M. (1996): Creativity: flow and the psychology of discovery and invention. New York: Harper Collins. Zagreb.

- Cvetković Lay, J., Sekulić Majurec, A. (1998): Darovito je, što ću s njim, Alinea,

- Čokorilo, R., Raič, A., Vuković, R. (1998): Mesto sporta u strukturi interesovanja omladine. Zbornik radova sa I. Međunarodnog simpozijuma: Inovacije nastavnih planova i programa fizičkog vaspitanja dece i omladine, Novi Sad, str. 199-207.

- Čudina-Obradović, M. (1990): Nadarenost, razumevanje, prepoznavanje, razvijanje. Školska knjiga, Zagreb.

- Đorđević, B., Radovanović, I., Božin, A., Radović, V. i Paser, V. (2007): Odrasli o darovitoj deci i mladima. Učiteljski fakultet u Beogradu i VŠV u Vršcu, 2007.

- Feberžer, I., Korez, I., Težak, S. (2006): Ali je ta otrok nadarjen? Cirkovce in Kidričevo.

- Gagne, F. (1994): Are teachers really poor talent detectors? Comments on Pegnato and Birch`s (1959) study of the effectiveness and efficiency of various identification techniques. Gifted Qvarterly, 38, 124-126.

- Havelka, N. i Lazarević, Lj. (1981): Sport i ličnost. Sportska knjiga, Beograd.

- Hulleman, C.S., Durik, A. M., Schweigert, S.A. and Harackiewicz, J.M. (2008): Task Values, Achievement Goals, and Interest: An Integrative Analysis, Journal of Educational Psychology, 2, 398-416.

- Iljin, I.P. (1985): Orijentacija i selekcija za različite vrste sportske aktivnosti na osnovu nadarenosti i sposobnosti. Zavod za fizičku kulturu, Beograd.

- Lazarević, D. (2000): Dečja interesovanja i stvaralaštvo, Zbornik 6, VŠV, Vršac.

- Malušić, S. (2000): Daroviti učenici i rad sa njima, EMKA, Beograd.

- Maksić, S. (1998): Darovito dete u školi. Institut za pedagoška istraživanja, Beograd.

- Maksić, S. (1999): Kreativnost između teorije i školske prakse, Zbornik Instituta za pedagoška istraživanja br.31, Beograd.

- Pantić, D. (1980): Interesovanja mladih, I deo - Priroda interesovanja, Istraživačkoizdavački centar SSo Srbije u saradnji sa Institutom društvenih nauka - OOUR Centar za politikološka istraživanja i javno mnjenje, Beograd.

- Radovanović, Đ., Milišević, Z. (2006): Mišljenje učenika petih razreda osnovne škole o nastavi fizičkog vaspitanja. Zbornik radova »Efekti diferencirane nastave fizičkog vaspitanja na psihosomatski status dece i omladine«, Fakultet fizičke kulture Univerziteta u Novom Sadu, Novi Sad, str. 71-111.

- Raič, A., Radovanović, Đ., Maksimović, N. (1998): Školska sredina i razvojne strategije mladih sportista. Zbornik radova sa I Međunarodnog simpozijuma: Inovacije nastavnih planova i programa fizičkog vaspitanja dece i omladine, Novi Sad, str. 185-198.

- Stanković-Janković, T. (2009): Interesovanje i motivacija kao činioci uspjeha u učenju. Zbornik radova »Inovacije u osnovnoškolskom obrazovanju - vrednovanje«, Učiteljski fakultet, Univerzitet u Beogradu, Beograd, str. 253-257.

- Sturza Milić, N. (2009): Identifikacija motorički darovitih učenika mlađeg školskog uzrasta. Doktorska disertacija, Fakultet sporta i fizičkog vaspitanja Univerziteta u Beogradu.

- Sturza Milić, N. (2009a): Identifikacija motorički darovitih učenika mlađeg školskog uzrasta. Visoka škola strukovnih studija za obrazovanje vaspitača »Mihailo Palov«, Vršac.

- Sturza Milić, N. (2009b): Diverzifikovana nastava fizičkog vaspitanja kao osnova razvoja motoričke uspešnosti i kreativnosti učenika, Monografija, Međunarodni znanstveni skup 
„Škola po mjeri““, Sveučilište Jurja Dobrile u Puli, Odjel za obrazovanje učitelja i odgajitelja, Hrvatska, str. 307-317.

- Šekeljić, G., Sturza Milić, N. (2010): Stavovi i interesovanje učenika za nastavne sadržaje i nastavu fizičkog vaspitanja, Zbornik radova »Obrazovanje i usavršavanje nastavnika didaktičko-metodički pristup«, Učiteljski fakultet u Užicu, Univerzitet u Kragujevcu, Užice, str. 425-434.

- Теплов, Б.А. (1961): Проблеми индивидуалних различиј, АПН РСФСР.

- Winner, E. (2000): The Origins and Ends of Giftedness. Boston College and Project Zero, Harvard Graduate School of Education, American Psychologist, 55,1,159.169. http://www.2.bc.edu/ winner/PDFs/originsandendGifftedness

Metodički obzori 7(2012)2

Izvorni znanstveni rad

UDK: $372.879 .6: 373.3$

Primljeno: 20. 12. 2010.

\title{
INTERESOVANJA - POKRETAČI STVARALAČKOG MOTORIČKOG UČENJA I POSTIGNUĆA UČENIKA
}

\author{
Dr. sc. Nataša Sturza Milić, \\ Visoka škola strukovnih studija za obrazovanje vaspitača \\ »Mihailo Palov«, Vršac (Serbia) \\ e-mail: natasasturza@gmail.com
}

\begin{abstract}
Rezime
Interesovanja spadaju u grupu motivacionih, dinamičnih osobina ličnosti, tako da se mogu posmatrati u svetlu značajnih unutrašnjih pokretača na aktivnost $u$ svim sferama stvaralaštva. Da bi škola bila podsticajna za dečje stvaralaštvo, trebalo bi da kod dece podrži radoznalost, intrinzičnu motivaciju, interesovanja za određene oblasti ljudske aktivnosti i stvaranja. Pojedini istraživački radovi na polju obrazovanja naglašavaju procese otkrivanja, praćenja i razvijanja posebnih interesovanja, kao uslov za uspeh obrazovanja u celini. Zbog značaja sagledavanja još nedovoljno ispitanih odnosa između sposobnosti, interesovanja i angažovanja učenika, pogotovo kada je u pitanju kvalitetna strategija rada sa motorički darovitim učenicima u okviru procesa fizičkog vaspitanja, cilj ovog rada bio je da se ispita da li postoji povezanost između motoričke uspešnosti učenika mlađeg školskog uzrasta i interesovanja prema fizičkoj aktivnosti. Rezultati pokazuju da je utvrđena statistički značajna korelacija $(r=0,549 ; p=0,00)$ između motoričke uspešnosti učenika i interesovanja prema fizičkoj aktivnosti, koja je prepoznata (procenjena) od strane učitelja. Rezultati ovog istraživanja mogu biti osnova za unapređivanje strategije rada sa učenicima u okviru nastavnih i vannastavih aktivnosti fizičkog vaspitanja i specijalnih školskih programa za darovite.
\end{abstract}

Ključne reči: interesovanja učenika, motorička uspešnost, fizičko vaspitanje 